\title{
Laborer Falls 55 to 75 Feet to the Ground While Spray Painting Grain Bins
}

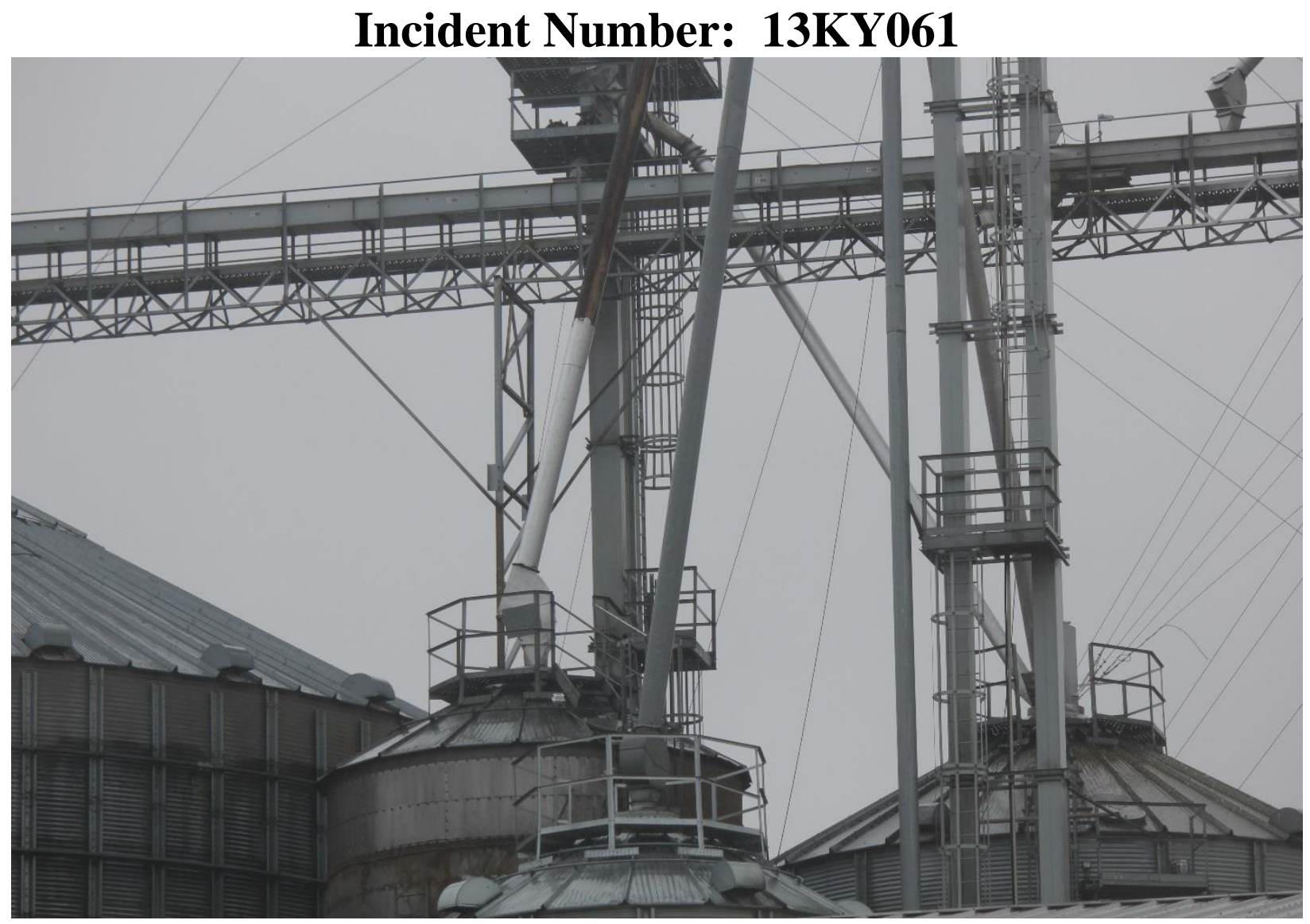

Photo courtesy of KY OSH

Kentucky Fatality Assessment and Control Evaluation Program Kentucky Injury Prevention and Research Center 333 Waller Avenue

Suite 242

Lexington, Kentucky 40504

Phone: 859-323-2981

Fax: 859-257-3909

www.kiprc.uky.edu

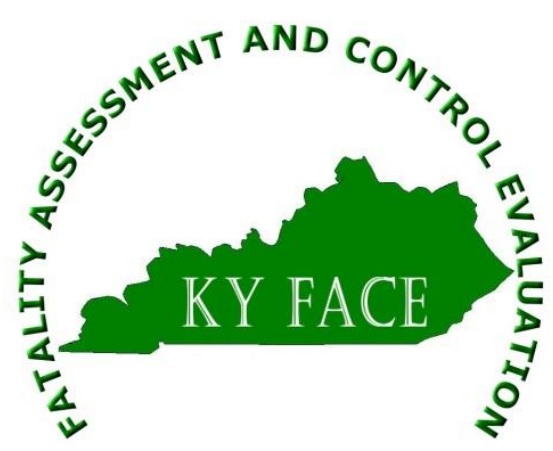




\section{Kentucky Fatality Assessment and Control Evaluation (FACE) Program Incident Number: 13KY061 \\ Release Date: November 11, 2014 \\ Subject: Laborer Falls 50 to 75 Feet to the Ground While Spray Painting Grain Bins}

\section{$\underline{\text { Introduction }}$}

On November 21, 2013, at 4:00pm, a 46-year-old painter, contracted to paint grain dryers at an agribusiness, fell 50 to 75 feet to his death. The victim was contracted through an outside vendor who had done previous work for the agribusiness. The agribusiness had suggested the contracted work begin in the spring, and the farmer was surprised when the vendor arrived in November. The weather was overcast, and it had rained the day before, when the vendor (two co-owners and two workers [one was the victim]) arrived at the worksite. The victim was shimmying down a grain spout holding a sprayer hose to paint a grain bin when he lost his grip and fell. He was not wearing any type of fall protection. One of the vendor co-owners heard a noise, went to investigate and found the victim lying on the concrete, unresponsive. The co-owner immediately dialed 911 at 4:00 pm. Emergency medical services arrived on the scene at 4:16 pm and assessed the victim as unresponsive with rapid shallow breathing. At 4:19 pm the victim was transported by helicopter to a local trauma center in the next state and pronounced dead at 7:35 pm.

To prevent future occurrences of similar incidents, the following recommendations have been made:

Recommendation No. 1: Regardless of company size, the employer must furnish proper personal protective equipment to employees conducting hazardous work.

Recommendation No. 2: Employers must train employees on how to properly wear the personal protective equipment provided as well as provide safety training for employees.

\section{$\underline{\text { Employer }}$}

The employer was an out-of-state painting and seal coating company that specialized in residential and commercial roofs, farm buildings, grain bins, driveways and parking lots. There were two occasional employees and two co-owners of this company. The employer did not have insurance or workers' compensation coverage to protect its employees as required. This was not considered a multiple employer arrangement because the grain bin owners did not supervise, direct, maintain any supervision on the contractor or provide any materials to the contractor. The owner was not on site when the fatality occurred. 


\section{Written Safety Programs and Training}

The employer had no written safety policies and there was no training provided to the workers. Fall protection was also absent at the scene.

\section{$\underline{\text { Victim }}$}

The victim was a 46-year-old black male recently released from prison and working for cash for the employer. The victim lived in a different state and traveled to Kentucky with the employer to paint grain bins. It is unknown how long the victim had been employed, but it is believed to have been 3-4 months.

\section{Incident Scene}

The incident scene was a large farm (see photo \#1). The site consisted of three 300,000-bushel bins, one 100,000-bushel bin, one 30,000-bushel wet bin, one 5,000-bushel load out-bin, a dryer bin, a feed mill and a control room/office. The grain elevator system ran from ground level to platforms $30 \mathrm{ft}$. above the bins. Downspouts running from the elevator delivered grain to the bins. The top of the elevator was approximately 130 feet high off the ground and the grain bins were 55 to 60 feet in height (see photo \#2). The dryer bin was equipped with a walking platform with railings. The employee was sliding down a 10 inch diameter down spout above the dryer bin, when he fell to the ground below, landing on the ground between the dyer bin, a wet bin and the control office.

\section{$\underline{\text { Weather }}$}

November 21, 2013 was an overcast day with temperatures ranging from 43 to 54 degrees Fahrenheit. It had rained on November $20^{\text {th }}$.

\section{Investigation}

The Kentucky Fatality Assessment and Control Evaluation Program was notified of an Occupational fatality involving a maintenance worker by the Kentucky Labor Cabinet on November 25, 2013.

The agribusiness had contacted an outside vendor to paint grain bins. This vendor, who had done previous work for the business, was told he could wait until spring to begin the task. Having expected the vendor in the spring, the agribusiness was surprised the vendor had arrived several months early in November. Both vendor co-owners were onsite, along with the victim and another employee.

It had been raining the previous day and was overcast the day of the incident; the surfaces of the grain bins were still damp. On November 21, 2013, between 7:00 and 7:30 a.m., the victim started painting the dryer bin, which was equipped with a walking platform with railings. It is unclear why the victim decided to hang from a 10 inch diameter downspout above the dryer bin without any type of fall protection. It was from this downspout that he lost his grip and fell 50- 
75 feet below to the concrete, between the dyer bin, a wet bin and the control office (see photo \#3).

One of the co-owners heard a noise, went to investigate and found the victim lying on the concrete, unresponsive. The co-owner immediately dialed 911 at 4:00 pm. Emergency medical services arrived on the scene at 4:16 pm and assessed the victim as unresponsive with rapid shallow breathing. At 4:19 pm the victim was transported by helicopter to a local trauma center in the next state, where he was pronounced dead at 7:35 pm.

\section{Cause of Death}

The cause of death was multiple blunt force injuries.

\section{$\underline{\text { Recommendations and Discussions }}$}

Recommendation No. 1: Regardless of company size, the employer must furnish proper personal protective equipment to employees conducting hazardous work.

When interviewed by Kentucky OSHA, the co-owners both stated that the victim had worn fall protection. However, it was noted in all emergency responder reports that no fall protection was found at the scene of the incident and was not on the victim's body when they arrived on scene.

The victim did not wear any type of body harness or fall protection to protect him in the event he fell while painting. Had the victim been wearing full body harness fall protection and been properly tied off, his harness would have prevented him from falling to the ground below when he slipped.

According to 29 CFR 1926.501 (b)(1): Each employee on a walking/working surface( horizontal and vertical surface) with an unprotected side or edge which was 6 feet $(1.8 \mathrm{~m})$ or more above a lower level shall be protected from falling by the use of guardrail systems, safety net systems, or personal fall arrest systems.

\section{Recommendation No. 2: Employers must train employees on how to properly wear the personal protective equipment provided as well as provide safety training for the employees.}

The victim and other employee were not trained on how to recognize fall hazards or how to properly wear personal protective equipment. Specific safety training is needed to identify work hazards and the necessary PPE.

29 CFR 1926.503 (a) (1) states that "the employer shall provide a training program for each employee who might be exposed to fall hazards. The program shall enable each employee to 
recognize the hazards of falling and shall train each employee in the procedures to be followed in order to minimize these hazards."

\section{Please take our survey regarding this report:}

https://www.surveymonkey.com/s/W2FR3CP

Keywords

Falls

Fall protection

Working with heights

Painting

\section{References}

https://www.osha.gov/pls/oshaweb/owadisp.show_document?p_id=10757\&p_table=STANDAR DS\#1926.501(b)(1)

https://www.osha.gov/pls/oshaweb/owadisp.show_document?p_table=STANDARDS\&p_id=107 $\underline{57}$

https://www.osha.gov/SLTC/fallprotection/standards.html

https://www.osha.gov/Publications/osha3071.pdf

https://www.osha.gov/workers.html\#2

\section{Acknowledgements}

The Kentucky FACE program would like to thank the agribusiness, the coroner, Kentucky Labor Cabinet and Kentucky OSHA for their assistance with this report.

The Kentucky Fatality Assessment \& Control Evaluation Program (FACE) is funded by grant 2U60OH008483-10 from the Centers for Disease Control and Prevention and the National Institute for Occupational Safety and Health. The purpose of FACE is to aid in the research and prevention of occupational fatalities by evaluating events leading to, during, and after a work related fatality. Recommendations are made to help employers and employees have a safer work environment. For more information about FACE and KIPRC, please visit our website: www.kiprc.uky.edu 


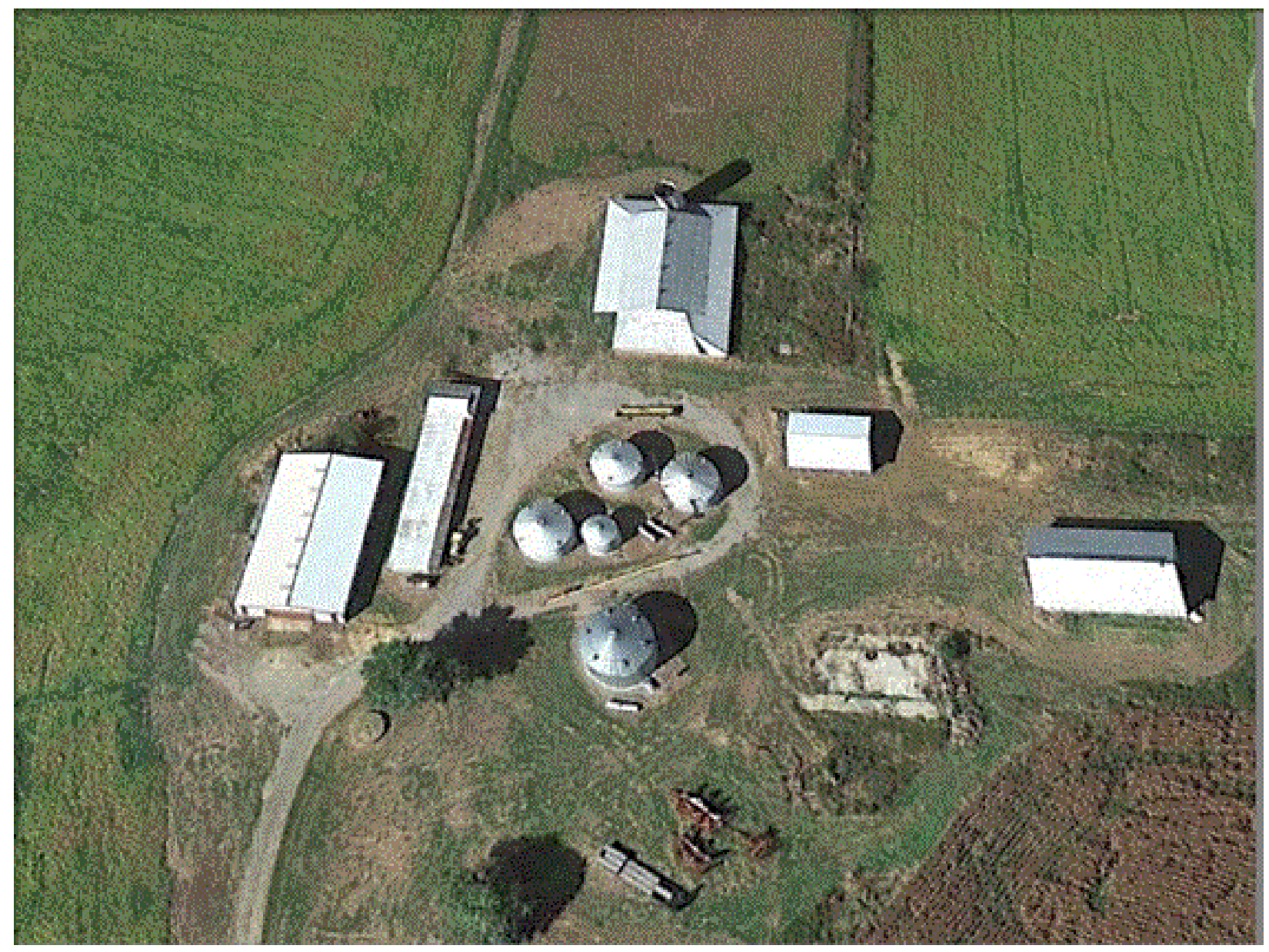

Photo \#1 overall view of incident scene

Photo courtesy of google earth 


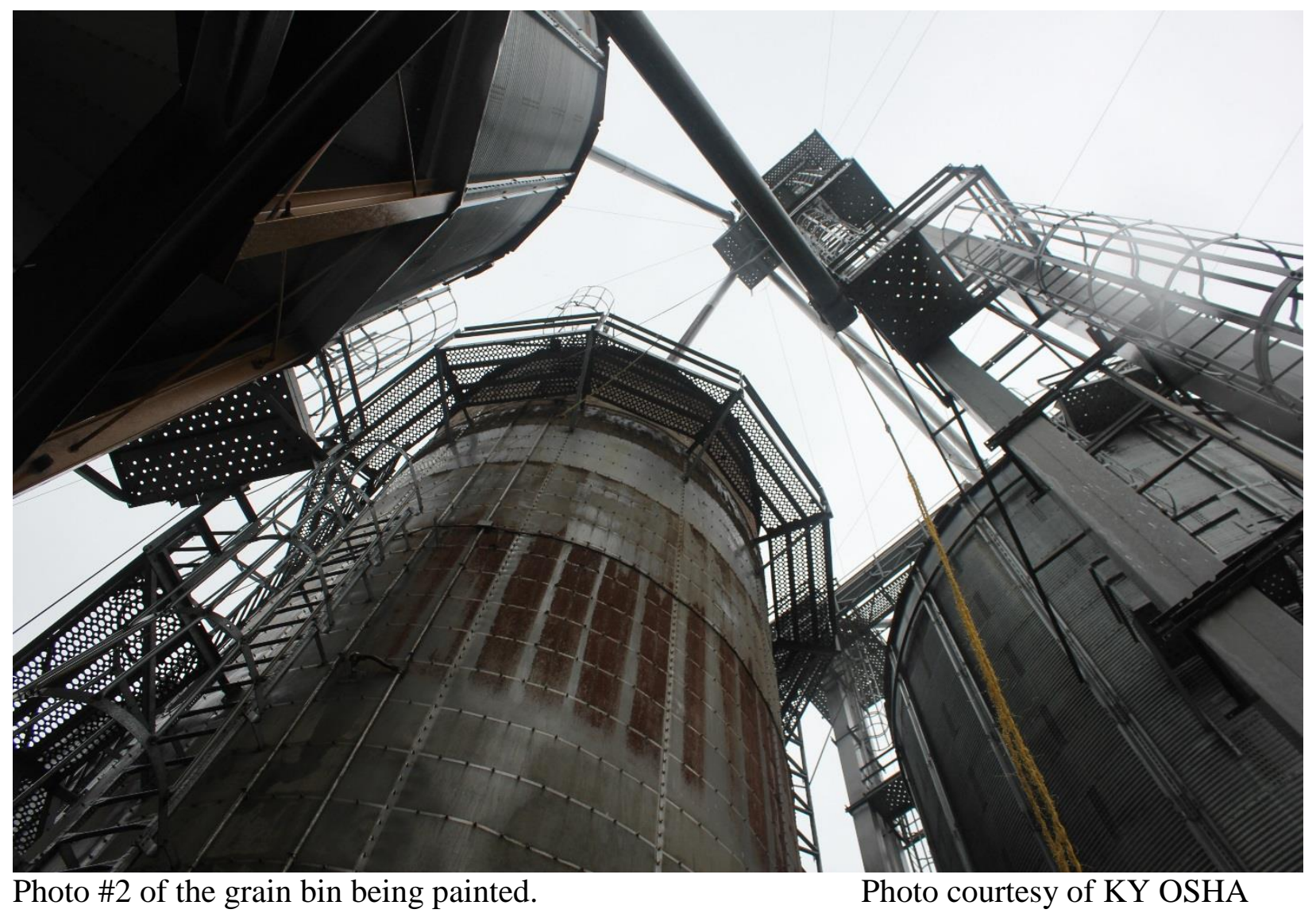




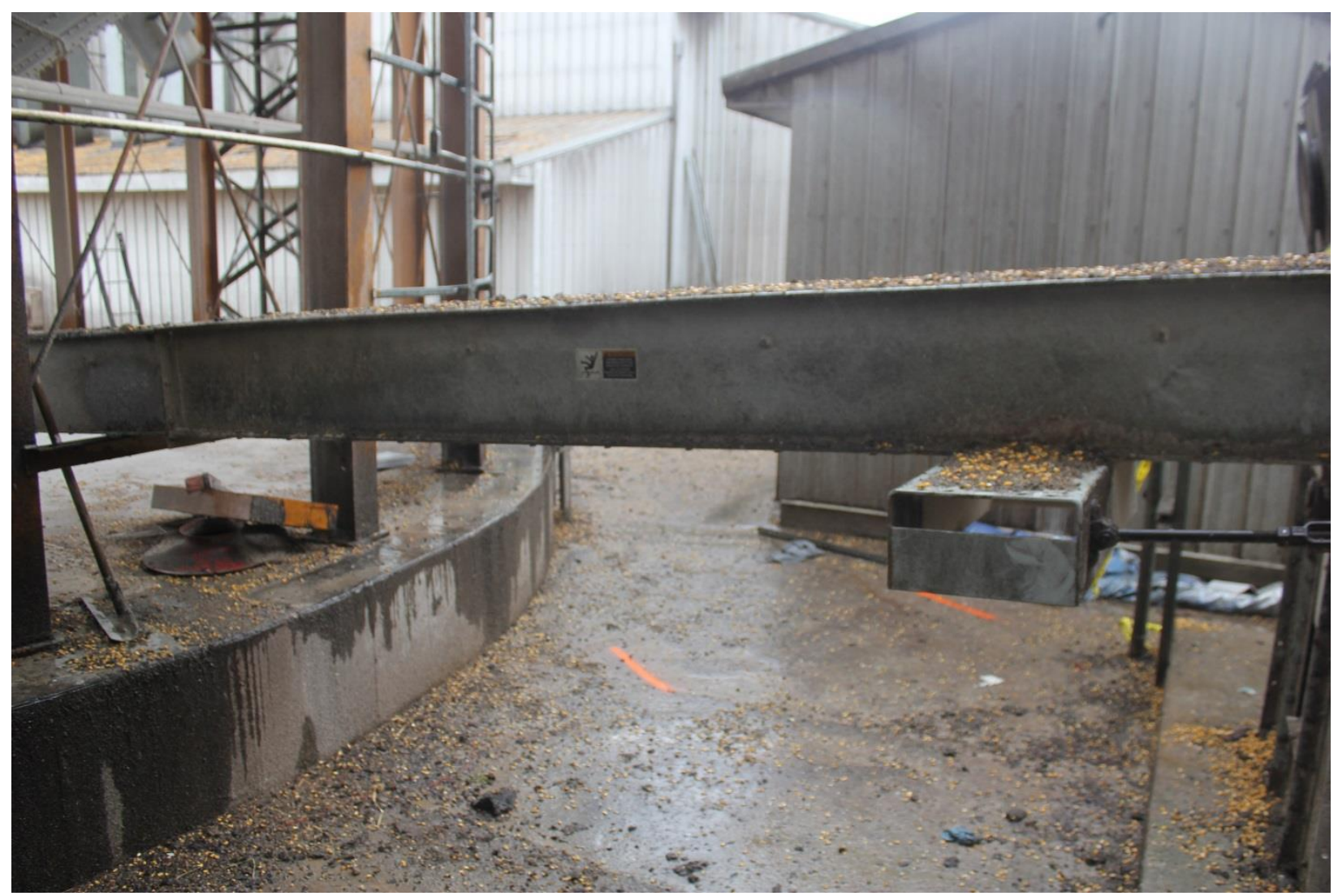

Photo \#3 is where the victim landed.

Photo courtesy of KY OSHA 